Creative commons User License: CC BY-NC-ND

Abstracted by: EBSCOhost, Electronic Journals Service (EJS),

Google Scholar, Directory of Open Access Journals (DOAJ),

Journal Seek, Scientific Commons,

Food and Agricultural Organization (FAO), CABI and Scopus
Journal of Agricultural Extension

Vol. XX (X) XXXXXX, 20XX

ISSN(e): 24086851; ISSN(Print); 1119944X

http://journal.aesonnigeria.org

http://www.ajol.info/index.php/jae

Email: editorinchief@aesonnigeria.org

\title{
Family Farming Practices in Taraba State
}

http://dx.doi.org/10.4314/jae.v20i2.6

\section{Emodi, A.I.}

Department of Agricultural Economics and Extension, University of Port Harcourt, Port Harcourt.

Email:emodizee@gmail.com

Phone: 08035536088

\section{Albert, C.O.}

Department of Agricultural and Applied Economics/Extension.

Rivers State University of Science and Technology, Port Harcourt.

Email: carobinedo@yahoo.com

Phone: 07031616233

\begin{abstract}
The study examined family farming practices in Taraba State. Structured interview schedule was used to elicit information from farmers. A total of 90 respondents were selected using stratified random sampling technique. Data collected were analysed using descriptive statistics. Findings from the study show that weeding ( $\bar{x}=2.67)$; planting of crops $(\bar{x}=3.11)$, application of fertilizer $(\bar{x}=3.02)$ and herbicides $(\bar{x}=2.83)$ were the farming activities practiced by family farmers. Social cohesion- unity and oneness in task execution ( $\bar{x}=3.00)$; safe-guard for food security $(\bar{x}=3.02)$; traditional practices in agriculture $(\bar{x}=3.00)$ and labour pools to reduce cost of labour $(\bar{x}=2.98)$ were some of the characteristics of family farming. Poor soil fertility $(\bar{x}=2.27)$, lack of finance $(\bar{x}=2.29)$, land tenure problems $(\bar{x}=2.12)$ and poor access road to farm land $(\bar{x}=2.32)$ were the challenges to family farming activities in the study area. It was concluded that family farming seems to have been in existence contributing to change in taste, demand for food varieties, food security and human nutrition.
\end{abstract}

Keywords: Family farming, farming activities, constraints to family farming

\section{Introduction}

In most countries family farming is the predominant form of agriculture in food production sector (FAO, 2014). This system of farming seems to be of communal settlement in which a household related by blood or by association settle as farming community. They include the father, mother, children, uncle and relatives carrying out farming as their sole occupation in farms away from home. It was a means of maintaining family patrimony, cultural heritage, and communities. Therefore, 
Creative commons User License: CC BY-NC-ND

Abstracted by: EBSCOhost, Electronic Journals Service (EJS),

Google Scholar, Directory of Open Access Journals (DOAJ),

Journal Seek, Scientific Commons,

Food and Agricultural Organization (FAO), CABI and Scopus
Journal of Agricultural Extension

Vol. XX (X) XXXXXX, 20XX

ISSN(e): 24086851; ISSN(Print); 1119944X

http://journal.aesonnigeria.org

http://www.ajol.info/index.php/jae

Email: editorinchief@aesonnigeria.org

motivations of family farmers go far beyond profit maximization to encompass social, cultural and ecological aspects. Ozowa (1995) stated that family farming is in both developed and developing countries economy. This is so because in a developed economy, one or two members of the farm family run the farm with mechanized method of farming to save human labour. Whereas in a developing economy, it comprises mainly of human labour, where most family members are directly involved and it is mostly carried out through subsistence farming.

Ozowa (1995) mentioned that though family farming might be labour intensive; not easily operational as mechanized farming, it is linked and co-evolves with economic functions, environmental and cultural values in performing its functions. Environmental functions can include soil enrichment, carbon sequestration and pest control. Reproductive functions could be caring for children, feeding and good nutrition, energy supply and water, education, health, soil security, insurance and risk management. Cultural functions include transmission of identity, religious values of resources, knowledge and technologies (Dugbazah, 2009). The contributions of family farmers to agricultural sustainability and development are essential to be acknowledged. Though Nigeria is perceived as an agrarian country, it mainly consists of subsistence farmers who use simple tools for farming (Emodi and Madukwe, 2010; Ani, 2013). The farmers traditionally produce cassava, millet, yam, cocoyam and livestock. These products are of energy-giving caloric foods which are not nutritionally balanced. This has resulted to malnutrition, marasmus kwashiorkor, ill health and fast aging among the farming community (Dugbazah, 2009).

Small holder farmers constitute a significant proportion of all farm holdings and play a central role in agricultural production, process, and implementation; about $95 \%$ of family farmers are rural dwellers (Albert and Igbokwe, 2014) while 5\% often attend to other family needs (Attah, 2012). The implication is the high rate of poverty, starvation and food insecurity in the country especially among the rural farmers. Among the family farmer's new knowledge in farm practice were shared through apprenticeship or learning by imitation (Attah, 2012). Through family farms communal life, they introduced to their farms improved seeds and animals from other 
Creative commons User License: CC BY-NC-ND

Abstracted by: EBSCOhost, Electronic Journals Service (EJS),

Google Scholar, Directory of Open Access Journals (DOAJ),

Journal Seek, Scientific Commons,

Food and Agricultural Organization (FAO), CABI and Scopus
Journal of Agricultural Extension

Vol. XX (X) XXXXXX, 20XX

ISSN(e): 24086851; ISSN(Print); 1119944X

http://journal.aesonnigeria.org

http://www.ajol.info/index.php/jae

Email: editorinchief@aesonnigeria.org

communities which they must have tried in their farms without the employment of formal extension agents (Swanson and Davis, 2014). The farmers have different talents and personality which they apply in solving arising problems, task and duties in the farm. Aregheore (2009) revealed that simple techniques of cultivation and production that is about two- third of Nigeria's agricultural production is relatively small, and of decreasing importance. Among family farmers' households there are values and norms, through communal live. Their offspring's learn by imitation through apprenticeship system. It has helped to solidify their family bonds and enable the children understand the meaning of respect for elders which is synonymous with African tradition (Agusiobo and Olaitan, 1982 in Aliber 2005). These farmers are faced with numerous challenges such as climate variability, lack of land tenure security for land and water, inputs, technology, training, research and advisory services education and limited access to markets (IFAD, 2014).

Insufficient food and poverty could be attributed to poor agricultural innovation dissemination which has far-reaching implications not only for the farm households but to national economy; it seem to have created poor food availability, accessibility and distribution problems at the farm families and national levels (Nyerhovwo and Douglason,2010). The bane of food security is that farming in Nigeria is predominately among small holders, who are not mechanized with farmers subjected to low level of agricultural production with hard labour which perpetuates poverty and hinders development (FAO, 2014). There is need for effective policies that will encourage increase access in supply of farm inputs such as pesticides, seeds, fertilizers, marketing of agricultural produce. Family farms seem to have been in existence contributing to change in taste, demand for food varieties, food security and human nutrition since the time of cave men. There is need for new ideas and improved technology for family farming to thrive for sustainable livelihood which can only be achieved on viable family farming (FAO, 2014; International Year of Family Farming, 2014). From this backdrop the study examined the extent family farming has thrived in farm activities among household farmers in Taraba State. 
Creative commons User License: CC BY-NC-ND

Abstracted by: EBSCOhost, Electronic Journals Service (EJS),

Google Scholar, Directory of Open Access Journals (DOAJ),

Journal Seek, Scientific Commons,

Food and Agricultural Organization (FAO), CABI and Scopus
Journal of Agricultural Extension

Vol. XX (X) XXXXXX, 20XX

ISSN(e): 24086851; ISSN(Print); 1119944X

http://journal.aesonnigeria.org

http://www.ajol.info/index.php/jae

Email: editorinchief@aesonnigeria.org

\section{Objectives of the study}

The main objective of the study was to assess family farming activities among farmers for increased agricultural productivity in Taraba State. The specific objectives were to:

i. describe the socio-economic characteristics of the respondents;

ii. identify family farming activities practiced by farmers;

iii. examine effects of family farming activities on agricultural development; and

iv. ascertain challenges to family farming practices in the study area.

\section{Methodology}

Taraba State consist of sixteen Local Government Areas with Ardo Kola, Lau, Jalingo, Karim Lamido, Yorro, Zing in the North, Gassol, Kurmi, Gashaka, Bali, Sardauna in the Central and Donga, Wukari, Ibi, Takum, Ussa in the south. The state is bounded in the west by Plateau and Benue states and on the east by the Cameroon. Taraba state lies largely within the tropical zone with an estimated land area of about 54,428 sq. $\mathrm{km}$, the state lies roughly between latitudes $6 \hat{\mathrm{A}}^{\circ} 25^{\prime} \mathrm{N}$ and $9 \hat{A}^{\circ} 30 ' \mathrm{~N}$ and between longitudes $9 \hat{A}^{\circ} 30^{\prime} \mathrm{E}$ and $11 \hat{A}^{\circ} 45^{\prime} \mathrm{E}$. It is bordered on the west by Gombe and Plateau States and by Adamawa State to the northeast. It also shares its south western boundary with Benue State and on the east is Republic of Cameroun. The major occupation of the people of Taraba State is agriculture. They produce cash crops such as coffee, tea, groundnuts and cotton (Umar, et al, 2014). Other crops produced are maize, rice, sorghum, millet cassava and yam in commercial quantity. Poultry, rabbit breeding, pig farming, cattle, sheep and goats are reared in large numbers. Other occupational activities such as pottery, clothweaving, dyeing, mat-making, carving, embroidery and blacksmithing are also carried out in various parts of the State (Online Nigeria, Community Portal of Nigeria, 2003).

The study was undertaken in three Local Government Areas of (Ardo Kola -North, Bali-Central, and Ussa-South) of Taraba State. The three Local Government Areas 
Creative commons User License: CC BY-NC-ND

Abstracted by: EBSCOhost, Electronic Journals Service (EJS),

Google Scholar, Directory of Open Access Journals (DOAJ),

Journal Seek, Scientific Commons,

Food and Agricultural Organization (FAO), CABI and Scopus
Journal of Agricultural Extension

Vol. XX (X) XXXXXX, 20XX

ISSN(e): 24086851; ISSN(Print); 1119944X

http://journal.aesonnigeria.org

http://www.ajol.info/index.php/jae

Email: editorinchief@aesonnigeria.org

were purposively selected based on their history of communal system of farming as well as cultivation of vegetable in the backyard gardening system. Secondly, two communities were randomly selected giving a total of six communities. Stratified random sampling was used to select fifteen families who are into family farming from the selected communities. A total of 90 respondents were selected using stratified random sampling technique, of which 30 respondents each were selected from each of the selected Local Government Area (LGA). For collecting relevant data from the respondents, questionnaire and personal interview schedule were used.

\section{Results and Discussion}

\section{Respondents' socio-economic characteristics}

Entries in Table 1 shows that the majority (68.3\%) of the respondents were males, single (54.9\%), had tertiary education (68.3\%) and had farming experience of 15 years and above (34.1\%). This implies that family farming is an ancient and common method of achieving food security, employment, shelter, income, and economic growth in the study area. It also implies that males and those who are not married dominate family farming in the study area. 
Creative commons User License: CC BY-NC-ND

Abstracted by: EBSCOhost, Electronic Journals Service (EJS),

Google Scholar, Directory of Open Access Journals (DOAJ),

Journal Seek, Scientific Commons,

Food and Agricultural Organization (FAO), CABI and Scopus
Journal of Agricultural Extension

Vol. XX (X) XXXXXX, 20XX

ISSN(e): 24086851; ISSN(Print); 1119944X

http://journal.aesonnigeria.org

http://www.ajol.info/index.php/jae

Email: editorinchief@aesonnigeria.org

\section{Table 1: Socio-economic characteristics of family farmers}

\begin{tabular}{|c|c|c|}
\hline Variables & Percent & Mean $(\bar{x})$ \\
\hline \multicolumn{3}{|l|}{ Gender } \\
\hline Male & 68.3 & \\
\hline Female & 31.7 & \\
\hline \multicolumn{3}{|l|}{ Marital Status } \\
\hline Single & 54.9 & \\
\hline Widowed & 7.3 & \\
\hline Married & 37.8 & \\
\hline \multicolumn{3}{|l|}{ Educational qualification } \\
\hline No formal education & 7.3 & \\
\hline Primary & 3.7 & \\
\hline Secondary uncompleted & 1.2 & \\
\hline Secondary completed & 18.3 & \\
\hline Vocational technical school & 1.2 & \\
\hline Tertiary education & 68.3 & \\
\hline \multicolumn{3}{|l|}{ Farming experience } \\
\hline 0-5years & 22.0 & \\
\hline $6-10$ years & 23.2 & \\
\hline 11-15years & 20.7 & 15 years \\
\hline $15 y r s$ and above & 34.1 & \\
\hline \multicolumn{3}{|l|}{ Farm Size (hectares) } \\
\hline $0.5-1 \mathrm{Ha}$ & 24.4 & \\
\hline 2-3Ha & 37.8 & $4 \mathrm{Ha}$ \\
\hline $4-5 \mathrm{Ha}$ & 17.1 & \\
\hline 5 and above 17 & 20.7 & \\
\hline \multicolumn{3}{|c|}{ Your entire household farm on the same farm? } \\
\hline YES & 58.5 & \\
\hline NO & 41.5 & \\
\hline \multicolumn{3}{|l|}{ Do you live in the farm house? } \\
\hline YES & 41.5 & \\
\hline \multirow{2}{*}{\multicolumn{3}{|c|}{$\begin{array}{l}\text { NO } \\
\text { Are you happy living in farm house? }\end{array}$}} \\
\hline & & \\
\hline YES & 42.7 & \\
\hline NO & 57.3 & \\
\hline \multicolumn{3}{|l|}{ Hours put per day in the farm } \\
\hline 1 & 41.5 & \\
\hline 2 & 13.4 & \\
\hline 3 & 9.8 & \\
\hline 4 & 9.8 & \\
\hline 5 & 9.8 & \\
\hline 6 & 3.7 & \\
\hline 7 & 8.5 & \\
\hline 8 & 2.4 & \\
\hline \multirow{2}{*}{\multicolumn{3}{|c|}{ Farm labour done by only farm household? }} \\
\hline & & \\
\hline YES & 53.7 & \\
\hline NO & 46.3 & \\
\hline
\end{tabular}

Source: Field work, 2015 
Creative commons User License: CC BY-NC-ND

Abstracted by: EBSCOhost, Electronic Journals Service (EJS),

Google Scholar, Directory of Open Access Journals (DOAJ),

Journal Seek, Scientific Commons,

Food and Agricultural Organization (FAO), CABI and Scopus
Journal of Agricultural Extension

Vol. XX (X) XXXXXX, 20XX

ISSN(e): 24086851; ISSN(Print); 1119944X

http://journal.aesonnigeria.org

http://www.ajol.info/index.php/jae

Email: editorinchief@aesonnigeria.org

\section{Relationship between farmers' personal characteristics and family farming}

Entries in Table 2 established that among the three models, linear and semi-log showed $R^{2}$ of 0.076 with education of the respondents significant at $5 \%$ level, indicating that education helps in increasing family farming activities among farmers in the study area. This is true because they will be better exposed to innovations brought by agricultural extension agents and will easily adopt new technologies. Linear, semi-log and double log regression results of gender, marital status, farming experience and farm size show that they are statistically insignificant in promoting family farming in the study area.

Table 2: Relationship between farmers' personal characteristics and family farming

\begin{tabular}{|c|c|c|c|c|c|c|c|c|c|}
\hline & \multicolumn{3}{|c|}{ Linear Model } & \multicolumn{3}{|c|}{ Semi-Log Model } & \multicolumn{3}{|c|}{$\begin{array}{l}\text { Double-Log } \\
\text { odel }\end{array}$} \\
\hline Variables & Coef & $\begin{array}{l}\text { Std } \\
\text { error }\end{array}$ & $\mathrm{t}$ - value & coef & $\begin{array}{l}\text { Std } \\
\text { error }\end{array}$ & t-value & Coef & $\begin{array}{l}\text { Std } \\
\text { error }\end{array}$ & $\begin{array}{l}\text { t- } \\
\text { value }\end{array}$ \\
\hline Gender & 0.36 & 0.112 & 0.318 & 0.014 & 0.046 & 0.318 & 0.032 & 0.067 & 0.477 \\
\hline $\begin{array}{l}\text { Marital } \\
\text { status }\end{array}$ & -0.48 & 0.049 & -0.973 & - & 0.020 & -0.973 & -0.044 & 0.043 & -1.025 \\
\hline Education & $-\overline{0.076}$ & -2.023 & $-0.031^{* *}$ & 0.31 & 0.015 & $-2.023^{\star *}$ & 0.047 & 0.047 & -1.864 \\
\hline $\begin{array}{l}\text { Farming } \\
\text { Experience }\end{array}$ & 0.025 & 0.058 & -0.420 & - & 0.024 & -0.420 & 0.001 & 0.056 & 0.017 \\
\hline $\begin{array}{l}\text { Farm size } \\
\mathrm{R}^{2}\end{array}$ & 0.036 & $\begin{array}{r}0.060 \\
0.0\end{array}$ & $\begin{array}{l}0.594 \\
76 \\
\end{array}$ & 0.014 & 0.024 & $\begin{array}{l}0.394 \\
0.076\end{array}$ & 0.017 & $\begin{array}{r}0.055 \\
0.0 \\
\end{array}$ & 0.301 \\
\hline
\end{tabular}

\section{Family farming activities practiced by farmers}

The results in Table 3 show the family farming activities practiced in the study area. Using a mean of 2.50 as the decision rule, the result established that family farmers were engaged in weeding ( $\bar{x}=2.67)$, application of herbicides $\quad(\bar{x}=2.83)$, planting of crops $(\bar{x}=3.11)$, food processing $(\bar{x}=2.63)$, creating ridges $(\bar{x}=2.74)$, engaged in labour $(\bar{x}=2.69)$ and harvesting $(\bar{x}=3.40)$. They were also involved in activities such as family heads making most managerial decisions $(\bar{x}=3.06)$ and application of fertilizer $(\bar{x}=3.02)$. The results indicate that family farming activities practiced in the study area were planting of crops, harvesting, application of fertilizers and making of 
Creative commons User License: CC BY-NC-ND

Abstracted by: EBSCOhost, Electronic Journals Service (EJS),

Google Scholar, Directory of Open Access Journals (DOAJ),

Journal Seek, Scientific Commons,

Food and Agricultural Organization (FAO), CABI and Scopus
Journal of Agricultural Extension

Vol. XX (X) XXXXXX, 20XX

ISSN(e): 24086851; ISSN(Print); 1119944X

http://journal.aesonnigeria.org

http://www.ajol.info/index.php/jae

Email: editorinchief@aesonnigeria.org

managerial decisions, food processing, creation of ridges, and application of herbicides, among others.

\section{Table 3: Percentage distribution of family farming activities practiced by} farmers

\begin{tabular}{lll}
\hline S/NO & Family farming activities & Mean $(\bar{x})$ \\
\hline 1 & Weeding & $2.67^{*}$ \\
2 & Mulching & 2.39 \\
3 & Stalking & 2.44 \\
4 & Application of herbicides & 2.83 \\
5 & The Head makes most of managerial decisions & 3.06 \\
6 & Planting of crops & 3.11 \\
7 & Application of fertilizer & 3.02 \\
8 & Family members provide capital to the business & 2.49 \\
9 & Engage in labour & 2.69 \\
10 & Farm involved in land integration & 2.72 \\
11 & Harvesting & 3.40 \\
12 & Food processing & 2.63 \\
13 & Creation of ridges & 2.74 \\
\hline
\end{tabular}

- mean $\geq 2.5=$ Accept

- Source: Field work, 2015

\section{Family farming activities on agricultural development}

Table 4 reveals that the respondents were of the view that family farming reduces poverty $(\bar{x}=3.19)$, provide household members with food and shelter $(\bar{x}=3.17)$, families could sell whatever is needed to gain cash for satisfying the range of other household needs of the family $(\bar{x}=3.16)$, indigenous agricultural knowledge was transmitted orally and through daily practices which aided agricultural development $(\bar{x}=3.07)$, it is seen as a safe-guard for food security $(\bar{x}=3.02)$, it is useful for good traditional practices in agriculture $(\bar{x}=3.00)$, it provides source of livelihood or employment for family members $(\bar{x}=3.01)$ and there is unity and oneness that helps in executing a task

$(\bar{x}=3.00)$. Others include: It pools labour in order to reduce cost of labour $(\bar{x}=2.98)$, It leads to social cohesion within communities $(\bar{x}=2.98)$, It is a tie to society between agricultural development among rural communities ( $\bar{x}=2.96)$ and family farm is the unit of broader connection with the community and territory $(\bar{x}=2.90)$. This is in agreement with the findings of (FAO, 2014), which stated that family farming provides food security and nutrition. 
Creative commons User License: CC BY-NC-ND

Abstracted by: EBSCOhost, Electronic Journals Service (EJS), Google Scholar, Directory of Open Access Journals (DOAJ), Journal Seek, Scientific Commons,

Food and Agricultural Organization (FAO), CABI and Scopus
Journal of Agricultural Extension

Vol. XX (X) XXXXXX, 20XX

ISSN(e): 24086851; ISSN(Print); 1119944X

http://journal.aesonnigeria.org

http://www.ajol.info/index.php/jae

Email: editorinchief@aesonnigeria.org

Table 4: Mean distribution of the effects of family farming activities on agricultural development

\begin{tabular}{|c|c|c|}
\hline $\mathrm{S} / \mathrm{NO}$ & Effects of family farming & Mean $(\bar{x})$ \\
\hline 1 & Supports in times of illness and old age & 2.88 \\
\hline 2 & Helps each other with cost of marriage & 2.86 \\
\hline 3 & $\begin{array}{l}\text { Family farm is the unit of broader connection with the community } \\
\text { and territory }\end{array}$ & 2.90 \\
\hline 4 & $\begin{array}{l}\text { It is a tie to society between agricultural development among rural } \\
\text { communities }\end{array}$ & 2.96 \\
\hline 5 & $\begin{array}{l}\text { Family farming is first to provide household members with food and } \\
\text { shelter }\end{array}$ & 3.16 \\
\hline 6 & $\begin{array}{l}\text { Sells whatever is needed to gain cash for satisfying the range of } \\
\text { other household needs }\end{array}$ & 3.17 \\
\hline 7 & It is essential for understanding and supporting agric. Development & 3.00 \\
\hline 8 & $\begin{array}{l}\text { Indigenous agric. knowledge transmitted orally and through daily } \\
\text { practices aid in agric. Development }\end{array}$ & 3.07 \\
\hline 9 & It is seen as a safe-guard for food security & 3.02 \\
\hline 10 & It is useful for good traditional practices in agriculture & 3.00 \\
\hline 11 & $\begin{array}{l}\text { It provides source of livelihood/employment for } \\
\text { family members }\end{array}$ & 3.01 \\
\hline 12 & There is unity and oneness that helps in executing a task & 3.00 \\
\hline 13 & It pools labour in order to reduce cost of labour & 2.98 \\
\hline 14 & It leads to social cohesion within communities & 2.98 \\
\hline 15 & It reduces poverty in the family & 3.19 \\
\hline
\end{tabular}

- mean $\geq 2.5=$ Accept

- Source: Field Survey, 2015

\section{Constraints to family farming activities}

The respondents were of the view (Table 5 ) that poor soil fertility $(\bar{x}=2.27)$, lack of finance $(\bar{x}=2.29)$, diseases/infection of crops $(\bar{x}=2.09)$, land acquisition problems ( $\bar{x}=2.22)$, high cost of agro-chemicals $(\bar{x}=2.22)$, competition of weeds $(\bar{x}=2.11)$ and land tenure problems $(\bar{x}=2.12)$. Others are poor access road to farmland $(\bar{x}=2.32)$, poor extension contact ( $\bar{x}=2.26$ ), and bad communication network ( $\bar{x}=2.06$ ), lack of organic fertilize $(\bar{x}=2.11)$, and High cost of transporting agric. produce from farm to market $(\bar{x}=2.22)$, lack of storage $(\bar{x}=2.27)$, and High cost of hired labour $(\bar{x}=$ 2.16). This result is in agreement with that of Ozowa (2015) which asserted that poor access road is a problem confronting small-scale farmers. Abajigi (2014) listed obstacles to family farming to include lack of finance, lack of access to extension services, socio-cultural conditions, among others. 
Creative commons User License: CC BY-NC-ND

Abstracted by: EBSCOhost, Electronic Journals Service (EJS),

Google Scholar, Directory of Open Access Journals (DOAJ),

Journal Seek, Scientific Commons,

Food and Agricultural Organization (FAO), CABI and Scopus
Journal of Agricultural Extension

Vol. XX (X) XXXXXX, 20XX

ISSN(e): 24086851; ISSN(Print); 1119944X

http://journal.aesonnigeria.org

http://www.ajol.info/index.php/jae

Email: editorinchief@aesonnigeria.org

Table 5: Constraints to family farming activities

\begin{tabular}{|c|c|c|}
\hline $\mathrm{S} / \mathrm{NO}$ & Constraints & $\begin{array}{l}\text { Mean } \\
(\bar{x})\end{array}$ \\
\hline 1 & Poor soil fertility & 2.27 \\
\hline 2 & Lack of finance & 2.29 \\
\hline 3 & Diseases/Infection & 2.09 \\
\hline 4 & Competition of weeds & 2.11 \\
\hline 5 & Land tenure problems & 2.12 \\
\hline 6 & Land acquisition problem & 2.22 \\
\hline 7 & Poor access road to farm land & 2.32 \\
\hline 8 & High cost of agro-chemicals & 2.22 \\
\hline 9 & Poor extension contact & 2.26 \\
\hline 10 & Bad communication network & 2.06 . \\
\hline 11 & Lack of inorganic fertilizer & 2.11 \\
\hline 12 & $\begin{array}{l}\text { High cost of transporting agricultural produce from } \\
\text { farm to market }\end{array}$ & 2.22 \\
\hline 13 & Lack of storage & 2.27 \\
\hline 14 & Processing facilities & 2.12 \\
\hline 15 & High cost of hired labour & 2.16 \\
\hline 16 & $\begin{array}{l}\text { Lack of credit for purchase of } \\
\text { equipment and input }\end{array}$ & 2.09 \\
\hline 17 & $\begin{array}{l}\text { The traditional rural family farm household has } \\
\text { changed because of migration/cultural } \\
\text { transformation }\end{array}$ & 2.24 \\
\hline 18 & Scarcity of farm lands & 2.02 \\
\hline 19 & Lack of access to modern farm technology & 2.00 \\
\hline 20 & Lack of access to improved planting materials & 2.18 \\
\hline 21 & The family members bear the risk alone & 2.17 \\
\hline 22 & $\begin{array}{l}\text { Once the head/leader is dead, it is difficult to } \\
\text { continue }\end{array}$ & 2.11 \\
\hline
\end{tabular}

- $\quad$ mean $\geq 2.5=$ Constraint

- Source: Field Survey, 2015

\section{Conclusion and Recommendations}

Different types of family farming activities are carried out by the farmers. These include: planting of crops, application of fertilizer and herbicides and weeding. This has led to increased social cohesion within families and communities through unity and oneness in executing tasks (farming). It helps to pool labour to reduce cost of labour, ensures security and it is useful for good traditional practices in agriculture in the study area. However, poor soil fertility, lack of finance, land tenure problems and 
Creative commons User License: CC BY-NC-ND

Abstracted by: EBSCOhost, Electronic Journals Service (EJS),

Google Scholar, Directory of Open Access Journals (DOAJ),

Journal Seek, Scientific Commons,

Food and Agricultural Organization (FAO), CABI and Scopus
Journal of Agricultural Extension

Vol. XX (X) XXXXXX, 20XX

ISSN(e): 24086851; ISSN(Print); 1119944X

http://journal.aesonnigeria.org

http://www.ajol.info/index.php/jae

Email: editorinchief@aesonnigeria.org

poor access road to farm land have slowed the practice of family farming activities in the study area.

The study recommends that credit facilities and fertilizers should be made available to these family farmers directly by stakeholders (Local, State and Federal government) to improve their soil and to farm more for increased agricultural productivity. Since family farming leads to increased social cohesion within families and reduces communal crisis, it should be encouraged as it will reduce communal crisis which has led to increased loss of lives in the nation.

\section{References}

Albert, C.O. \& Igbokwe, E.M. (2014). Assessment of rural livelihoods in oil producing communities of Rivers State, Nigeria. Agricultura, Agricultural Practice and Science Journal, 1-2 (89-90): 103-108.

Aliber, M. (2005). Synthesis and conclusions In: Aliber, M., De Swart, C., Du Toit, A.,Mbhele, $\mathrm{T}$ and Mthethwa, $\mathrm{T}$ (eds). Trends and policy challenges in the Rural Economy: Four Provincial Case Studies. Human Sciences Research Council Research Monograph, Employment and Economic Policy Research Programme. Cape Town: Human Sciences Research Council (HSRC) Press.

Ani, A.O. (2013). Contemporary Issues in Programme Planning, Implementation, Monitoring and Evaluation in Agricultural Extension. Ibadan: BWright Integrated Publishers

Aregheore, E.M. (2009). Country Pasture/Forage Resource Profiles Nigeria www.fao.org/ag/agp/agpc/doc/counprof/PDF\%20files/Nigeria.pdf

Attah, A.W. (2012). Food Security in Nigeria: The Role of Peasant Farmers in Nigeria. An InternationalMultidisciplinary Journal, Vol. 6 (4):173-190. http://www.ajol.info/index.php/afrrev/article/view/83605/73633

Dugbazah, J. (2009). The relationships between values, religious teaching and development concepts and in practices: A preliminary literature review. Working Paper, 33. Accessed on $8^{\text {th }}$ December, 2015 from http://www.birmingham.ac.uk/Documents/college-socialsciences/government-society/research/rad/working-papers/wp-33.pdf 
Creative commons User License: CC BY-NC-ND

Abstracted by: EBSCOhost, Electronic Journals Service (EJS),

Google Scholar, Directory of Open Access Journals (DOAJ),

Journal Seek, Scientific Commons,

Food and Agricultural Organization (FAO), CABI and Scopus
Journal of Agricultural Extension

Vol. XX (X) XXXXXX, 20XX

ISSN(e): 24086851; ISSN(Print); 1119944X

http://journal.aesonnigeria.org

http://www.ajol.info/index.php/jae

Email: editorinchief@aesonnigeria.org

Emodi, A. I. \& Madukwe, M.C. (2010). Linkage mechanisms among key actors in Rice innovation system in Southeast Nigeria. Journal of Agricultural Extension, 14 (2):56-60

Food and Agriculture Organisation (FAO) (2014). Family Farmers- Feeding the world, caring for the earth: World Food Day Celebration Report Accessed on $28^{\text {th }}$ December, 2015 from http://www.fao.org/3/a-i4621e.pdf

Food and Agriculture Organisation (FAO) (2014). International Year of Family Farming Accessed on $4^{\text {th }}$ December, 2015 from

http://www.fao.org/family-farming-2014/home/what-is-family-farming/en/

Food and Agriculture Organisation of the United Nations (FAO) (2014). The state of Food and Agriculture: Innovation in Family Farming.

http://www.fao.org/publications/sofa/2014/en/

International Fund for Agricultural Development (IFAD) (2014).International Year of Family Farming: IFAD's commitment and call for action. Accessed on $8^{\text {th }}$ December, 2015 from https://www.ifad.org/documents/10180/5fe2f0d8-4b434598-8b7b-429ee24b6635

International Year of Family Farming (2014). Accessed on $8^{\text {th }}$ November, 2015 from http://www.fao.org/family-farming-2014/home/what-is-family-farming/en/

Nierenberg, D. (2014). Global forum on food security and nutrition. http://www.fao.org/fsnforum/activities/discussions/family-farming

Nyerhovwo, J.T. \& Douglason, G. O. (2010). Biotechnology and food security in developing countries Biotechnology and Molecular Biology Reviews. 5 (1): 013-023.

http://www.academicjournals.org/article/article1380106339_Tonukari\%20a nd\%200motor.pdf (retrieved17/05/2015)

Online Nigeria, Community Portal of Nigeria 2003(retrieved15/05/2015)

Ozowa, V.N. (1995) Information Needs of Small Scale Farmers in Africa: The Nigerian Example. Quarterly Bulletin of the International Association of Agricultural Information Specialists, 4(1)

Umar, M.H., Nyameh, J. \& Jauro, J. (2014). Agricultural management strategy on food security in Taraba State. Journal of Biology, Agriculture and Healthcare, 4(8):29-31.www.iitse.org 
Creative commons User License: CC BY-NC-ND

Abstracted by: EBSCOhost, Electronic Journals Service (EJS),

Google Scholar, Directory of Open Access Journals (DOAJ),

Journal Seek, Scientific Commons,

Food and Agricultural Organization (FAO), CABI and Scopus
Journal of Agricultural Extension

Vol. XX (X) XXXXXX, 20XX

ISSN(e): 24086851; ISSN(Print); 1119944X

http://journal.aesonnigeria.org

http://www.ajol.info/index.php/jae

Email: editorinchief@aesonnigeria.org

Swanson, B.E. \& Davis, K. (2014).Status of Agricultural Extension and Rural Advisory Services Worldwide. GFRAS-Status of Rural Advisory Services Worldwide.doc 